\title{
PERJALANAN PANJANG ILMU ADMINISTRASI PUBLIK (DARI PARADIGMA KLASIK MENUJU KONTEMPORER)
}

\author{
Imanuel Jaya
}

\begin{abstract}
ABSTRAK
Tulisan ini memberikan gambaran yang jelas mengenai perjalanan panjang ilmu administrasi publik dari waktu ke waktu, di mana akan terlihat pergeseran sudut pandang mengenai posisi pemerintah terhadap masyarakat maupun sebaliknya. Dalam tulisan ini tergambar bagaimana awal mula munculnya konsep administrasi yang secara jelas terpisah dari induknya yaitu ilmu politik hingga paradigma terakhir yaitu New Public Service.

Tidak dapat dipungkiri bahwa tulisan ini berakar dari pemikiran Denhardt dan Denhardt (2004) yang termuat dalam bukunya The New Public Service: Serving, Not Steering yang membagi paradigma administrasi publik menjadi 3 (tiga) yaitu Old Public Administration (OPA), New Public Management (NPM), dan New Public Service (NPS) dan tulisan ini juga memuat kritik-kritik terhadap masing-masing paradigma tersebut.
\end{abstract}

\section{Kata kunci : Old Public Administration, New Public Management, New Public Service}

\section{PENDAHULUAN}

Di dalam sistem ketatanegaraan suatu negara, model penyelenggaraan pemerintahan mempunyai posisi yang sangat berpengaruh terhadap jalannya sistem pemerintahan. Setiap model dari penyelenggaraan pemerintahan dipengaruhi oleh paradigma yang sedang berkembang dalam ranah Administrasi Publik pada saat tersebut. Begitu berpengaruhnya sebuah paradigma sampai-sampai setiap negara mengadopsi hal-hal prinsipil yang berkaitan dengan sebuah paradigma ke dalam sistem pemerintahannya bahkan sampai level pemerintahan di tingkat lokal terendah.

Tindakan yang dilakukan pemerintah dalam hal ini tidak lain adalah dalam rangka mencari cara yang lebih tepat dalam rangka memberikan pelayanan yang sebaik-baiknya kepada masyarakat guna mencapai kesejahteraan masyarakat seperti yang telah menjadi tujuan dari Administrasi Publik itu sendiri.

Ilmu Administrasi Publik dalam hal ini mengalami beberapa kali pergeseran paradigma yang berawal dari paradigma Old Public Administration (OPA) sekitar tahun 1885/1887 sampai 1980an akhir, New Public Management (NPM) yang berkembang pada akhir 1980an sampai pertengahan 1990an dan juga New Public Service (NPS) yang berkembang sejak pertengahan tahun 1990an hingga sekarang.

Indonesia dalam hal ini juga tidak dapat melepaskan diri dari pengaruh perkembangan paradigma administrasi publik yang terjadi. Pengaruh paradigma ini sangat kuat tertanam sampai pada posisi pemerintahan di tingkat lokal, yang juga mempengaruhi bagaimana hubungan antara pemerintah dengan masyarakat yang dilayaninya dan juga antara pemerintah dengan para politisi.

Tulisan ini berusaha untuk memetakan kembali pergeseran paradigma di dalam Ilmu Administrasi Publik agar dapat terlihat batas-batas karakteristik antar masing-masing paradigma ilmu Administrasi Publik.

\section{LATAR BELAKANG / SEJARAH PERKEMBANGAN}

Karena karakteristik antara birokrasi pemerintah dan organisasi swasta sangat berbeda, maka para ilmuwan dan praktisi administrasi negara menyadari pentingnya mengembangkan teori dan pendekatan yang berbeda dengan yang dikembangkan oleh para ilmuwan yang 
mengembangkan teori-teori administrasi bisnis. Dengan kesadaran baru tersebut maka identitas Ilmu Administrasi Negara menjadi semakin jelas, yaitu ilmuwan administrasi negara lebih menempatkan proses administrasi sebagai pusat perhatian (fokus) dan lembaga pemerintah sebagai tempat praktik (lokus). Pada titik ini dapat disimpulkan bahwa kelahiran Ilmu Administrasi Negara sangat dipengaruhi oleh dua cabang ilmu, yaitu Ilmu Politik dan Ilmu Manajemen. Kesadaran bahwa Ilmu Administrasi Negara tidak dapat terlepas dari Ilmu Politik, karena proses administrasi pemerintahan tidak terlepas dari proses politik, dan realitas bahwa prinsip-prinsip administrasi tidak dapat diterapkan secara general pada organisasi pemerintah dan swasta sekaligus semakin mengukuhkan pemahaman bahwa yang dimaksud dengan Ilmu Administrasi Negara adalah ilmu tentang bagaimana proses administrasi pemerintahan dikelola secara baik dengan menggunakan prinsip-prinsip manajemen yang sesuai dengan pembentukan organisasi pemerintah, yaitu untuk mengatur, melayani dan melindungi kepentingan publik. Dengan pencapaian tersebut, Dwiyanto (2007:109) menyebut bahwa Ilmu Administrasi Negara tumbuh menjadi sebuah ilmu yang semakin dewasa dan mampu menyejajarkan dirinya dengan induknya, yaitu Ilmu Politik dan Ilmu Manajemen.

Teori dalam administrasi negara dapat dilacak dari perkembangan paradigma ilmu administrasi negara itu sendiri. Pada awalnya, paradigma adalah konsep yang digunakan oleh kalangan ilmuwan natural science untuk menjelaskan fenomena perkembangan ilmu. Namun kemudian, paradigma juga dipakai oleh scientist ilmu-ilmu sosial untuk memetakan perkembangan ilmu sosial. Pada prinsipnya paradigma adalah cara pandang sekelompok orang atau pakar dalam melihat dan menganalisis fenomena sosial yang berkembang di tengah masyarakat. Paradigma juga digunakan sebagai landasan filosofis dan ideologis dalam menelaah dan mengkritisi isu-isu sosial. Paradigma seringkali dikonotasikan sebagai perspektif atau paham oleh sebagian orang. Konsep paradigma berawal dari pemikiran Thomas S. Kuhn. Kuhn mendefinisikan paradigma sebagai:

"The overarching set of accepted, and most of the time unquestioned beliefs that are jointly held by researchers and praticioners in a discipline...it is characterized by a symbolic generalizations, shared commitment to a specific set of beliefs by members of the discipline and shared values"

Paradigma administrasi Negara sudah jauh bergeser dan meninggalkan pendulum dikotomi politik-administrasi. Dalam konteks kekinian, paradigma dikotomi politikadministrasi yang terkenal dengan adagium when political end, administrative begin kurang relevan dengan perkembangan teori dan praktik administrasi negara. Bahkan sebenarnya, administrasi negara sudah lama meninggalkan paradigma ke-5 dalam ilmu administrasi negara yaitu administrasi negara sebagai administrasi negara (1970-?) sebagaimana yang dikemukakan oleh Henry. Henry hanya menentukan bahwa paradigma ke-5 dimulai sejak tahun 1970, tetapi ia tidak memberi batasan sampai berapa lama paradigma ke-5 bertahan. Sejak 1990 sampai saat ini teori dan konsep administrasi negara sudah berkembang sangat pesat, terutama dengan munculnya paradigma New Public Management (NPM) pada permulaan tahun 1990 yang kemudian disusul oleh New Public Service (NPS) pada tahun 2000an.

Dalam memahami teori administrasi negara secara paradigmatik, tulisan Janet V. Denhardt dan Robert B. Denhardt yang berjudul The New Public Service: Serving, not Steering dapat digunakan untuk menemukenali perkembangan paradigma administrasi negara klasik sampai administrasi negara kontemporer. Tulisan tersebut diterbitkan pertama kali dalam bentuk buku pada tahun 2003 di New York. Sejak kemunculannya buku ini mendapat respon yang positif dari kalangan cendikiawan administrasi negara karena dianggap mampu memberikan perspektif alternatif dalam memandang administrasi negara.

Sebelum terbit berbentuk buku, pada tahun 2000 Denhardt dan Denhardt sudah pernah mempublikasikan tulisan yang sama, namun dengan judul yang berbeda yaitu The New Public 
Service: Serving Rather than Steering dalam jurnal Public Administration Review. Kemudian disusul dengan tulisan yang lain tetapi kurang lebih dengan ide yang sama dalam International Review of Public Administration pada tahun 2003, dengan judul The New Public Service: An Approach to Reform. Buku yang diterbitkan pada tahun 2003 adalah repetisi dan modifikasi dari dua tulisan yang pernah muncul sebelumnya.

Denhardt dan Denhardt mencoba membagi paradigma administrasi Negara atas tiga kelompok besar, yaitu paradigma The Old Public Administration (OPA), The New Public Management (NPM) dan The New Public Service (NPS). Menurut Denhardt dan Denhardt paradigma OPA dan NPM kurang relevan dalam mengaddres persoalan-persoalan publik karena memiliki landasan filosofis dan ideologis yang kurang sesuai (inappropriate) dengan administrasi Negara, sehingga perlu paradigma baru yang kemudian disebut sebagai NPS.

\section{PARADIGMA ADMINISTRASI NEGARA MODEL KLASIK / OLD PUBLIC ADMINISTRATION (OPA)}

Paradigma OPA tidak bisa dipisahkan dari tiga pemikiran, yaitu paradigma dikotomi politik-administrasi, rational-model Herbert Simon dan teori pilihan publik (public choice). Pertama, paradigma dikotomi politik-administrasi yang mencoba menawarkan gagasan pemisahan politik-administrasi sebagaimana yang dikemukakan oleh Henry. Paradigma dikotomi politik-administrasi memiliki dua kunci pokok yang menjadi tema ide mereka; (i) Politik berbeda (distinct) dengan administrasi. Secara naluriah, politik adalah arena dimana kebijakan (policy) diambil sehingga administrasi tidak berhak berada dalam arena tersebut. Pejabat-pejabat politik (elected agencies) bertanggung-jawab mengartikulasikan kepentingan publik dan memformulasikannya menjadi sebuah produk politik berupa kebijakan. Administrasi hanya bertugas mengimplementasikan (administered) kebijakan tersebut. Dengan demikian, maka fungsi politik dan administrasi harus dipisahkan agar tidak saling mempengaruhi (politisasi-birokrasi). Administrasi tidak boleh terkooptasi oleh kepentingan politik sehingga birokrasi menjadi profesional dan netral dalam menjalankan kebijakan publik; (ii) Pimpinan pada setiap level dalam organisasi administrasi juga harus mampu menata struktur dan strategi organisasi yang memungkinkan organisasi mencapai tujuannya dengan efisien. Atasan diberikan keleluasaan untuk memberikan punishment kepada bawahan yang lalai.

OPA juga tidak bisa dilepaskan dari prinsip-prinsip manajemen ilmiah (scientific management) Frederick W. Taylor dan manajemen klasik POSDCORB ciptaan Luther Gullick. Administrasi negara harus berorientasi secara ketat kepada efisiensi. Semua sumber daya (man, material, machine, money, method, market) digunakan sebaik-baiknya untuk mencapai prinsip efisiensi. Aparat pemerintah harus bertindak sesuai petunjuk pelaksanaan (juklak) dan petunjuk teknis (juknis) dengan sangat rigid dan kaku. Tidak ada ada celah bagi birokrasi untuk menggunakan diskresinya karena dikhawatirkan dapat mengurangi efisiensi. Pejabat pada level atas (top-management) diminta untuk mengontrol bawahan dengan otoritas-birokratik secara top-down.

Kedua, manusia rasional (administratif) Herbert Simon juga memberikan pengaruh terhadap OPA. Menurut Simon, manusia dipengaruhi oleh rasionalitas mereka dalam mencapai tujuan-tujuannya. Rasionalitas yang dimaksud di sini hampir sama dengan efisiensi yang dikemukakan oleh aliran scientific management. Manusia yang bertindak secara rasional ini disebut dengan manusia administratif (administrative man). Manusia administratif adalah orang yang memiliki perilaku yang rasional untuk mencapai tujuan organisasi dan tujuan pribadinya. Orang yang bekerja di dalam organisasi juga memiliki motif pribadi yang harus dipenuhi oleh organisasi. Tujuan pribadi ini tidak selalu uang, tetapi bisa juga pengakuan, rasa ingin dihormati dan dihargai serta keinginan untuk menunjukkan jati diri. 
Ketiga, teori pilihan publik (public choice) merupakan teori yang melekat (asociate) dalam OPA. Teori pilihan publik berasal dari filsafat manusia ekonomi (economic man) dalam teori-teori ekonomi. Inti ajaran teori pilihan publik menyatakan bahwa manusia adalah individu yang rasional yang selalu menginginkan terpenuhinya kebutuhan pribadinya (self-interested) dan memaksimalkan keuntungan pribadinya (own-utilities). Menurut teori pilihan publik manusia akan selalu mencari keuntungan atau manfaat yang paling tinggi pada setiap situasi dalam setiap pengambilan keputusan. Manusia diasumsikan sebagai makhluk ekonomi yang selalu mencari keuntungan pribadi melalui serangkaian keputusan yang mampu memberikan manfaat yang paling tinggi.

Ilmu Administrasi Negara lahir sejak Woodrow Wilson (1887), yang kemudian menjadi presiden Amerika Serikat pada 1913-1921, menulis sebuah artikel yang berjudul "The Study of Administration” yang dimuat di jurnal Political Science Quarterly. Kemunculan artikel itu sendiri tidak lepas dari kegelisahan Wilson muda akan perlunya perubahan terhadap praktik tata pemerintahan yang terjadi di Amerika Serikat pada waktu itu yang ditandai dengan meluasnya praktik spoil system (sistem perkoncoan) yang menjurus pada terjadinya inefektivitas dan inefisiensi dalam pengelolaan negara. Studi Ilmu Politik yang berkembang pada saat itu ternyata tidak mampu memecahkan persoalan tersebut karena memang fokus kajian Ilmu Politik bukan pada bagaimana mengelola pemerintahan dengan efektif dan efisien, melainkan lebih pada urusan tentang sebuah konstitusi dan bagaimana keputusan-keputusan politik dirumuskan. Dalam tulisannya tersebut Wilson (1887: 1) mengatakan:

"No one wrote systematically of administration as a branch of the science of government until the present century had passed it first youth and had begun to put forth its characteristic flower of systematic knowledge. Up to our own day all the political writers whom we now read and though, argued, dogmatized, only about the constitution of governments; about nature of the state, the essence and seat of sovereignty, popular power and kingly prerogative...The central field of controversy was that great field of theory in which monarchy rode tilt against democracy, in which oligarchy would have built for itself strongholds of privilege, and in which tyranny sought opportunity to make good its claim to receive submission from all competitors. The question, how law should be administered with enlightenment, with equity, with speed, and without friction, was put aside as a practical detail which clerks could arrange after doctor had agreed upon principles”

Menurut Wilson, Ilmuwan Politik lupa bahwa kenyataannya lebih sulit mengimplementasikan konstitusi dengan baik dibanding dengan merumuskan konstitusi itu sendiri. Sayangnya ilmu yang diperlukan untuk itu belum ada. Oleh karena itu, untuk dapat mengimplementasikan konstitusi dengan baik maka diperlukan suatu ilmu yang kemudian disebut Wilson sebagai Ilmu Administrasi. Ilmu yang oleh Wilson disebut ilmu administrasi tersebut menekankan dua hal, yaitu perlunya efisiensi dalam mengelola pemerintahan dan perlunya menerapkan merit system dengan memisahkan urusan politik dari urusan pelayanan publik. Agar pemerintahan dapat dikelola secara efektif dan efisien, Wilson juga menganjurkan diadopsinya prinsip-prinsip yang diterapkan oleh organisasi bisnis "the field of administration is the field of business".

Penjelasan ilmiah terhadap gagasan Wilson tersebut kemudian dilakukan oleh Frank J. Goodnow yang menulis buku yang berjudul: "Politics and Administration” pada 1900. Buku Goodnow tersebut seringkali dirujuk oleh para ilmuwan administrasi negara sebagai

"proklamasi" secara resmi terhadap lahirnya Ilmu Administrasi Negara yang memisahkan diri dari induknya, yaitu Ilmu Politik. Era ini juga sering disebut sebagai era paradigma dikotomi 
politik-administrasi. Melalui paradigma ini, Ilmu Administrasi Negara mencoba mendefinisikan eksistensinya yang berbeda dengan Ilmu Politik dengan ontologi, epistimologi dan aksiologi yang berbeda. Beberapa tahun kemudian, sebuah buku yang secara sistematis menjelaskan apa sebenarnya Ilmu Administrasi Negara lahir dengan dipublikasikannya buku Leonard D. White yang berjudul "Introduction to the Study of Public Administration” pada 1926. Buku White yang mencoba merumuskan sosok Ilmu Administrasi tersebut pada dasarnya sangat dipengaruhi oleh berbagai karya ilmuwan sebelumnya yang mencoba menyampaikan gagasan tentang bagaimana suatu organisasi seharusnya dikelola secara efektif dan efisien, seperti Frederick Taylor (1912) dengan karyanya yang berjudul "Scientific Management”, Henry Fayol (1916) dengan pemikirannya yang dituangkan dalam monograf yang berjudul "General and Industrial Management", W.F. Willoughby (1918) dengan karyanya yang berjudul "The Movement for Budgetary Reform in the State”, dan Max Weber (1946) dengan tulisanya yang berjudul "Bureaucracy". Era berikutnya merupakan periode di mana para ilmuwan administrasi negara berusaha membangun body of knowledge ilmu ini dengan terbitnya berbagai artikel dan buku yang mencoba menggali apa yang mereka sebut sebagai prinsip-pinsip administrasi yang universal. Tonggak utama dari era ini tentu saja adalah munculnya artikel L. Gulick (1937) yang berjudul "Notes on the Theory of Organization” di mana dia merumuskan akronim yang terkenal dengan sebutan POSDCORDB (Planning, Organizing, Staffing, Directing, Co-ordinating, Reporting dan Budgeting). Tidak dapat dipungkiri, upaya para ahli administrasi negara untuk mengembangkan body of knowledge ilmu administrasi negara sangat dipengaruhi oleh ilmu manajemen. Prinsip-prinsip administrasi sebagaimana dijelaskan oleh para ilmuwan tersebut pada dasarnya merupakan prinsip-prinsip administrasi yang diadopsi dari administrasi bisnis yang menurut mereka dapat juga diterapkan di organisasi pemerintah.

Perkembangan pergulatan pemikiran ilmuwan administrasi negara diwarnai sebuah era pencarian jati diri Ilmu Administrasi Negara yang tidak pernah selesai. Kegamangan para ilmuwan administrasi negara dalam meninggalkan induknya, yaitu Ilmu Politik, untuk membangun eksistensinya secara mandiri bermula dari kegagalan mereka dalam merumuskan apa yang mereka sebut sebagai prinsip-prinsip administrasi sebagai pilar pokok Ilmu Administrasi Negara. Keruntuhan gagasan tentang prinsip-prinsip administrasi ditandai dengan terbitnya tulisan Paul Applebey (1945) yang berjudul “Government is Different”. Dalam tulisannya tersebut Applebey berargumen bahwa institusi pemerintah memiliki karakteristik yang berbeda dengan institusi swasta sehingga prinsip-prinsip administrasi yang diadopsi dari manajemen swasta tidak serta merta dapat diadopsi dalam institusi pemerintah. Karya Herbert Simon (1946) yang berjudul "The Proverbs of Administration” semakin memojokkan gagasan tentang prinsip-prinsip administrasi yang terbukti lemah dan banyak aksiomanya yang keliru. Kenyataan yang demikian membuat Ilmu Administrasi Negara

mengalami "krisis identitas" dan mencoba menginduk kembali ke Ilmu Politik.

Namun demikian, hal ini tidak berlangsung lama ketika ilmuwan administrasi negara mencoba menemukan kembali fokus dan lokus studi ini. Kesadaran bahwa lingkungan pemerintahan dan bisnis cenderung mengembangkan nilai, tradisi dan kompleksitas yang berbeda mendorong perlunya merumuskan definisi yang jelas tentang prinsip-prinsip administrasi yang gagal dikembangkan oleh para ilmuwan terdahulu. Dwiyanto (2007) menjelaskan bahwa lembaga pemerintah mengembangkan nilai-nilai dan praktik yang berbeda dengan yang berkembang di swasta (pasar) dan organisasi sukarela. Mekanisme pasar bekerja karena dorongan untuk mencari profit, sementara lembaga pemerintah bekerja untuk mengatur, melayani dan melindungi kepentingan publik.

Secara ringkas, Denhardt dan Denhardt menguraikan karakteristik OPA sebagai berikut: 
1. Fokus utama adalah penyediaan pelayanan publik melalui organisasi atau badan resmi pemerintah.

2. Kebijakan publik dan administrasi negara dipahami sebagai penataan dan implementasi kebijakan yang berfokus pada satu cara terbaik (on a single), kebijakan publik dan administrasi negara sebagai tujuan yang bersifat politik.

3. Administrator publik memainkan peranan yang terbatas dalam perumusan kebijakan publik dan pemerintahan; mereka hanya bertanggung-jawab mengimplementasikan kebijakan publik.

4. Pelayanan publik harus diselenggarakan oleh administrator yang bertanggung-jawab kepada pejabat politik (elected officials) dan dengan diskresi terbatas.

5. Administrator bertanggung-jawab kepada pimpinan pejabat politik (elected political leaders) yang teleh terpilih secara demokratis.

6. Program-program publik dilaksanakan melalui organisasi yang hierarkis dengan kontrol yang ketat oleh pimpinan organisasi.

7. Nilai pokok yang dikejar oleh organisasi publik adalah efisiensi dan rasionalitas.

8. Organisasi publik melaksanakan sistem tertutup sehingga keterlibatan warga negara dibatasai.

9. Peranan administrator publik adalah melaksanakan prinsip-prinsip Planning, Organizing, Staffing, Directing, Coordinating, Reporting dan Budgetting.

\section{Kritik terhadap OPA}

Seiring dengan adanya sejumlah kritikan sebagaimana yang diungkapkan Stoker (2004) membuat paradigma Administrasi Publik model klasik mulai melemah pada akhir tahun 1970an dan memberikan jalan terhadap komsep Manajemen Publik. Kritik yang ditujukan terhadap Administrasi Publik model klasik seringkali dikaitkan dengan karakteristik yang dianggap inter alia, red tape, lamban, tidak seensitif terhadap kebutuhan masyarakat, penggunaan sumber daya publik yang sia-sia akibat hanya berfolus kepada proses dan prosedur dibandingkan kepada hasil, sehingga muncul pandangan negatif dari masyarakat yang menganggap Adminiistras Publik sebagai beban besar para pembayar pajak (Economic and Social Council UN, 2004)

Kritik terhadap Administrasi Publik model klasik juga dilihat dalam kaitannya dengan keberadaan konsep "Birokrasi Ideal” dari Weber yang mana menurut (Prasojo : 2003) terdapat setidaknya 2 (dua) titik kritis terhadap birokrasi Weberian yakni pertama, dalam hubungan dantara masyarakat dan negara, implementasi birokrasi sering ditandai dengan meningkatnya intensitas perundang-undangan dan juga kompleksitas peratuan; kedua, struktur birokrasi dalam hubungannya dengan masyarakat seringkali dikritisi sebagai penyebab menjamurnya mejameja pelayanan sekaligus menjadi penyebab jauhnya birokrasi dari rakyat. Peningkatan intensitas dianggap memiliki resiko di mana pada akhirnya akan menyebabkan intervensi negara yang akan menyentuh semua aspek kehidupan masyarakat dan pada akhirnya menyebabkan biaya penyelenggaraan birokrasi menjadi sangat mahal.

\section{PARADIGMA NEW PUBLIC MANAGEMENT (NPM)}

\section{Sejarah Munculnya New Public Management}

Munculnya kritik yang keras yang ditujukan kepada organisasi-organisasi sector publik menimbulkan gerakan untuk melakukan reformasi manajemen sektor publik. Salah satu gerakan reformasi sektor public itu adalah munculnya konsep New PublicManagement. New Public Management telah mempengaruhi proses perubahan organisasi sektor publik secara komprehensif di hampir seluruh dunia. Penekanan gerakan New Public Management tersebut adalah pada pelaksanaan desentralisasi, devolusi, dan modernisasi pemberian pelayanan publik. Istilah New Public Management pada awalnya dikenalkan oleh Christopher 
Hood tahun 1991, ia kemudian menyingkat istilah tersebut menjadi NPM (Lihat: Hughes, 1998). Ditinjau dari perspektif historis, pendekatan manajemen modern di sector publik tersebut pada awalnya muncul di Eropa tahun 1980-an dan 1990-an sebagai reaksi dari tidak memadainya model administrasi publik tradisional. Pada perkembangannya, pendekatan manajerial modern tersebut memiliki banyak sebutan, misalnya: ,, managerialism, " „, new public management," „Market-based public administration," „postbureaucratic paradigm, " dan „entrepreneurial government. "Istilah yang kemudian banyak dipakai untuk menyebut model manajemen publik modern tersebut adalah New Public Management. Istilah New Public Management dan Managerialism sering saling menggantikan, namun istilah New Public Management-lah yang kemudian banyak dipakai. Adanya berbagai nama untuk menyebut pendekatan manajemen modern di sektor publik tersebut pada dasarnya bermuara pada pandangan umum yang sama. Pertama, perubahan model manajemen publik tersebut menunjukkan adanya pergeseran besar dari model administrasi public tradisional menuju sistem manajemen publik modern yang memberikan perhatian yang lebih besar terhadap pencapaian kinerja dan akuntabilitas manajer publik. Kedua, perubahan itu menunjukkan adanya keinginan untuk bergerak meninggalkan model birokrasi klasik menuju model organisasi modern yang lebih fleksibel. Ketiga, perlunya dibuat tujuan organisasi yang jelas dan tujuan personal. Hal itu berdampak pada perlunya dilakukan pengukuran atas prestasi yang mereka capai melalui indikator kinerja. Terdapat evaluasi program secara sistematik. Keempat, staf senior tampaknya secara politis lebih commit terhadap pemerintah saat itu daripada bersikap netral atau nonpartisan. Kelima, fungsi pemerintah tampaknya akan lebih banyak berhadapan dengan pasar, misalnya tender, yang oleh Osborne dan Gaebler (1992) disebut "catalytic government: steering rather than rowing." Keterlibatan pemerintah tidak selalu berarti pemfasilitasan pemerintah melalui sarana birokrasi. Keenam, terdapat kecenderungan untuk mengurangi fungsi pemerintah melalui privatisasi dan bentuk lain dari marketisasi sektor publik (Hughes, 1998, pp. 52-53). NPM merupakan teori manajemen publik yang beranggapan bahwa praktik manajemen sektor swasta adalah lebih baik dibandingkan dengan praktik manajemen pada sektor publik. Oleh karena itu, untuk memperbaiki kinerja sektor publik perlu diadopsi beberapa praktik dan teknik manajemen yang diterapkan di sektor swasta ke dalam organisasi sektor publik, seperti pengadopsian mekanisme pasar, kompetisi tender (Compulsory Competitive Tendering- CCT), dan privatisasi perusahaan-perusahaan publik (Hughes, 1998; Jackson, 1995; Broadbent \& Guthrie, 1992).

Penerapan konsep New Public Management telah menyebabkan terjadi perubahan manajemen sektor publik yang drastis dari sistem manajemen tradisional yang kaku, birokratis, dan hierarkis menjadi model manajemen sektor publik yang fleksibel dan lebih mengakomodasi pasar. Penerapan konsep NPM dapat dipandang sebagai suatu bentuk modernisasi atau reformasi manajemen dan administrasi publik, depolitisasi kekuasaan, atau desentralisasi wewenang yang mendorong demokrasi. Perubahan tersebut juga telah mengubah peran pemerintah terutama dalam hal hubungan antara pemerintah dengan masyarakat (Hughes, 1998). Beberapa pihak meyakini bahwa paradigma New Public Management merupakan sebuah fenomena internasional sebagai bagian dari proses global. Konsep NPM begitu cepat mempengaruhi praktik manajemen publik di berbagai negara sehingga membentuk sebuah gerakan yang mendunia.

\section{Manajemen Publik Vs Administrasi Publik}

New Public Management merupakan suatu paradigma alternatif yang menggeser model administrasi publik tradisional. Terdapat pro dan kontra terhadap manajerialisme yang terjadi pada organisasi sektor publik. Bagi yang pro mereka memandang NPM menawarkan suatu cara baru dalam mengelola organisasi sektor publik dengan membawa fungsi-fungsi 
manajemen sektor swasta ke dalam sektor publik. Sementara itu, bagi yang kontra mereka mengkritik bahwa pengadopsian prinsip-prinsip manajemen sektor swasta ke dalam sektor publik tersebut merupakan adopsi yang tidak kritis. Tidak semua praktik manajemen sektor swasta baik. Jika sektor publik mengadopsi praktik manajemen sektor swasta maka hal itu juga berarti mengadopsi keburukan di sektor swasta ke dalam sektor publik. Selain itu, pengadopsian itu juga mengabaikan perbedaan yang fundamental antara organisasi sektor publik dengan sektor swasta. Manajerialisme menurut mereka yang kontra bertentangan dengan prinsip demokrasi. Kritik dari pendukung administrasi publik menyatakan bahwa halhal baik yang terdapat dalam model lama, seperti: standar etika yang tinggi dan pelayanan kepada negara, menjadi dikesampingkan apabila sektor publik mengadopsi prinsip manajerialisme. Manajerialisme juga dicurigai sebagai bentuk kapitalisme yang masuk ke sektor publik. Namun meskipun berbagai kritikan muncul, model baru manajemen sektor publik tersebut terus berkembang baik secara teori maupun praktik. Konsep NPM dengan cepat mampu menggeser pendekatan administrasi publik tradisional. Mengapa manajerialisme mengalami perkembangan yang pesat dalam organisasi sektor publik? Kebutuhan terhadap manajerialisme dalam organisasi sektor publik adalah karena adanya tuntutan masyarakat yang semakin besar agar sektor publik bisa menghasilkan produk (barang/jasa) yang memiliki kualitas yang lebih baik atau minimal sama dengan yang dihasilkan sektor swasta. Jika sektor publik masih tetap berpaku pada pendekatan administrasi, maka sektor publik akan gagal menjawab tantangan tersebut. Oleh karena itu, organisasi sektor publik perlu mengadopsi prinsip-prinsip manajerialisme.

Konsep New Public Management pada dasarnya mengandung tujuh komponen utama, yaitu:

1. Manajemen profesional di sektor publik

2. Adanya standar kinerja dan ukuran kinerja

3. Penekanan yang lebih besar terhadap pengendalian output dan outcome

4. Pemecahan unit-unit kerja di sektor publik

5. Menciptakan persaingan di sektor publik

6. Pengadopsian gaya manajemen di sektor bisnis ke dalam sektor publik

7. Penekanan pada disiplin dan penghematan yang lebih besar dalam menggunakan sumber daya

\section{New Public Management Di Negara Berkembang}

Reformasi sektor publik pada dasarnya tidak hanya terjadi di negara-negara maju saja. Akan tetapi beberapa negara berkembang juga secara aktif terus melakukan reformasi lembaga publiknya. Reformasi sektor publik di negara berkembang banyak dipengaruhi oleh peran World Bank, UNDP, IMF, dan OECD. Reformasi sektor publik di negara-negara yang sedang berkembang banyak yang mengarah pada penerapan New Public Management. Perubahan yang dilakukan oleh negara-negara berkembang tersebut bercermin kepada perubahan manajerial yang dilakukan oleh negara-negara maju terutama Inggris, Amerika Serikat, Kanada, dan New Zealand. Beberapa pihak berpendapat bahwa New Public Management tidak tepat diterapkan untuk negara berkembang. Pengadopsian model New Public Management yang dilakukan negara-negara berkembang apakah memang benar-benar menjadikan lebih baik ataukan hanya sekedar perubahan luarnya saja. Apakah manajerialisme yang dilakukan di negara-negara maju bisa diimplementasikan di negara berkembang. Hal tersebut menjadi pertanyaan mendasar, karena gaya manajemen yang ada di negara-negara Barat mungkin sekali akan berbeda hasilnya jika diterapkan di tempat yang berbeda. Sangat mungkin terjadi bahwa penerapan NPM dipengaruhi oleh faktor-faktor kultural. Tingkat keberhasilan negara berkembang dalam mengadopsi prinsip manajerialism model barat memang bervariasi. Sebagai contoh, Malaysia menerapkan Total Quality Management (TQM) sebagai bentuk dari modernisasi manajemen publik dan penerapannya dinilai sukses, namun 
Bangladesh dan beberapa negara Afrika banyak mengalami kegagalan. Implementasi New Public Management di negara-negara berkembang tidak mudah dilakukan karena kecenderungan birokrasi masih sangat sulit dihilangkan. Argumen bahwa New Public Management tidak tepat untuk negara-negara berkembang karena alasan korupsi dan rendahnya kapasitas administrasi tidaklah tepat. Penerapan NPM pada negara-negara berkembang tergantung pada faktor-faktor kontinjensi lokal (localised contingency) bukan karena karakteristik nasional secara umum. Faktor-faktor seperti korupsi dan lemahnya kemampuan administrasi memang mempengaruhi kinerja pemerintah, akan tetapi localised contingencies lebih besar pengaruhnya sebagai penentu keberhasilan atau kegagalan upaya reformasi.

\section{Permasalahan Dalam Penerapan New Public Management}

Terdapat beberapa masalah dalam menerapkan konsep New Public Management di negara berkembang. Pertama, New Public Management didasarkan pada penerapan prinsip/mekanisme pasar atas kebijakan publik dan manajemennya. Hal ini juga terkait dengan pengurangan peran pemerintah yang digantikan dengan pengembangan pasar, yaitu dari pendekatan pemerintah sentris (state centered) menjadi pasar sentris (market centered approach). Negara-negara berkembang memiliki pengalaman yang sedikit dalam ekonomi pasar. Pasar di negara berkembang relatif tidak kuat dan tidak efektif. Perekonomian pasarnya lebih banyak didominasi oleh asing atau perusahaan asing, bukan pengusaha pribumi atau lokal. Di samping itu, pasar di negara berkembang tidak efektif karena tidak ada kepastian hukum yang kuat. Sebagai contoh, masalah kepatuhan terhadap kontrak kerja sama (contract right) sering menjadi masalah. Kedua, terdapat permasalahan dalam privatisasi perusahaanperusahaan publik. Privatisasi di negara berkembang bukan merupakan tugas yang mudah. Karena pasar di negara berkembang belum kuat, maka privatisasi akhirnya akan berarti kepemilikan asing atau kelompok etnis tertentu yang hal ini dapat membahayakan, misalnya menciptakan keretakan sosial. Ketiga, Perubahan dari mekanisme birokrasi ke mekanisme pasar apabila tidak dilakukan secara hati-hati bisa menciptakan wabah korupsi. Hal ini juga terkait dengan permasalahan budaya korupsi yang kebanyakan dialami negara-negara berkembang. Pergeseran dari budaya birokrasi yang bersifat patronistik menjadi budaya pasar yang penuh persaingan membutuhkan upaya yang kuat untuk mengurangi kekuasaan birokrasi. Keempat, terdapat masalah untuk berpindah menuju pada model pengontrakan dalam pemberian pelayanan publik jika aturan hukum dan penegakannya tidak kuat. Model pengontrakan akan berjalan baik jika outcomenya mudah ditentukan. Jika tujuan organisasi tidak jelas, atau terjadi wabah korupsi yang sudah membudaya maka penggunaan modelmodel kontrak kurang berhasil. Terdapat permasalahan politisasi yang lebih besar di negara berkembang dibandingkan di negara maju, termasuk dalam hal politisasi penyediaan pelayanan publik, pemberian kontrak kepada kroni-kroninya. Kelima, kesulitan penerapan New Public Management di negara berkembang juga terkait dengan adanya permasalahan kelembagaan, lemahnya penegakan hukum, permodalan, dan kapabilitas sumber daya manusia. terjadi karena Selain itu, negara berkembang terus melakukan reformasi yang tidak terkait atau bahkan berlawanan dengan agenda NPM. Paket dalam agenda NPM tidak dilaksanakan sepenuhnya.

Paradigma OPA dikritik oleh paradigma NPM. Secara konseptual OPA berbeda dengan NPM. NPM mengacu kepada sekelompok ide dan praktik kontemporer untuk menggunakan pendekatan-pendekatan dalam sektor privat (bisnis) pada organisasi sektor publik. NPM adalah suatu gerakan yang mencoba menginjeksikan prinsip-prinsip organisasi sektor privat ke dalam organisasi pemerintah. Pemerintahan yang kaku dan sentralistik sebagaimana yang dianut oleh OPA harus diganti dengan pemerintahan yang berjiwa 
wirausaha dan profitable. NPM sering diasosiasikan juga dengan managerialism (Pollitt), market-based public administration (Land dan Rosenbloom), post-bureaucratic paradigm (Barzelay) dan entrepreneurial government (Osborne dan Gaebler).

Keban (2004:95) menyatakan bahwa NPM merupakan genealogis dari ideologi neoliberalisme karena menganjurkan pelepasan fungsi-fungsi pemerintah kepada sektor swasta. Inti dari ajaran NPM dapat diuraikan sebagai berikut:

1. Pemerintah diajak untuk meninggalkan paradigma administrasi tradisional dan menggantikannya dengan perhatian terhadap kinerja atau hasil kerja.

2. Pemerintah sebaiknya melepaskan diri dari birokrasi klasik dan membuat situasi dan kondisi organisasi, pegawai dan para pekerja lebih fleksibel.

3. Menetapkan tujuan dan target organisasi dan personel lebih jelas sehingga memungkinkan pengukuran hasil melalui indikator yang jelas.

4. Staf senior lebih berkomitmen secara politis dengan pemerintah sehari-hari daripada netral.

5. Fungsi pemerintah adalah memperhatikan pasar, kontrak kerja keluar, yang berarti pemberian pelayanan tidak selamanya melalui birokrasi, melainkan bisa diberikan oleh sektor swasta.

6. Fungsi pemerintah dikurangi melalui privatisasi.

Penerapan paradigma NPM sangat sukses di Amerika Serikat, Inggris dan Selandia Baru sehingga "virusnya” mulai menyebar ke negara-negara lain. Praktik NPM di Amerika Serikat populer dengan pemerintahan wirausaha (entrepreneurial government) yang dirancang oleh David Osborne dan Ted Gaebler. Osborne dan Gaebler menawarkan 10 prinsip pemerintahan yang berjiwa wirausaha.

1. Pemerintahan katalis; pemerintahan yang mengarahkan bukan mengayuh.

2. Pemerintahan milik masyarakat; pemerintahan yang memberdayakan bukan melayani.

3. Pemerintahan kompetetif; pemerintahan yang menginjeksikan semangat kompetisi dalam pelayanan publik.

4. Pemerintahan yang digerakkan oleh misi; pemerintahan yang mampu merubah orientasi dari pemerintahan yang digerakkan oleh aturan.

5. Pemerintahan yang berorientasi hasil; pemerintahan yang membiayai hasil bukan input.

6. Pemerintahan yang berorientasi pelanggan; pemerintahan yang memenuhi kebutuhan pelanggan bukan birokrasi.

7. Pemerintahan wirausaha; pemerintahan yang menghasilkan profit bukan menghabiskan.

8. Pemerintahan antisipatif; pemerintahan yang berorientasi pencegahan bukan penyembuhan.

9. Pemerintahan desentralisasi; merubah pemerintahan yang digerakkan oleh hierarki menjadi pemerintahan partisipatif dan kerjasama tim.

10. Pemerintahan yang berorientasi pasar; pemerintahan yang mendorong perubahan melalui pasar.

\section{PARADIGMA NEW PUBLIC SERVICE (NPS)}

Dalam pandangan NPM, organisasi pemerintah diibaratkan sebagai sebuah kapal. Menurut Osborne dan Gaebler, peran pemerintah di atas kapal tersebut hanya sebagai nahkoda yang mengarahkan (steer) lajunya kapal bukan mengayuh (row) kapal tersebut. Urusan kayuhmengayuh diserahkan kepada organisasi di luar pemerintah, yaitu organisasi privat dan organisasi masyarakat sipil sehingga mereduksi fungsi domestikasi pemerintah. Tugas pemerintah yang hanya sebagai pengarah memberikan pemerintah energi ekstra untuk mengurus persoalan-persoalan domestik dan internasional yang lebih strategis, misalnya persoalan meningkatkan pertumbuhan ekonomi dan perdagangan luar negeri. 
Paradigma steering rather than rowing ala NPM dikritik oleh Denhardt dan Denhardt sebagai paradigma yang melupakan siapa sebenarnya pemilik kapal (who owned the boat). Seharusnya pemerintah memfokuskan usahanya untuk melayani dan memberdayakan warga negara karena merekalah pemilik "kapal”. Selengkapnya, Denhardt dan Denhardt menulis sebagai berikut,

In our rush to steer, perhaps we are forgetting who owns the boat...Accordingly, public administrators should focus on their responsibility to serve and empower citizens as they manage public organizations and implement public policy. In other words, with citizens at the forefront, the emphasis should not be placed on either steering or rowing tha governmental boat, but rather on building public institutions marked by integrity and responsiveness.

Perspektif new public service mengawali pandangannya dari pengakuan atas warga negara dan posisinya yang sangat penting bagi kepemerintahan demokratis. Jati diri warga negara tidak hanya dipandang sebagai semata persoalan kepentingan pribadi (self interest) namun juga melibatkan nilai, kepercayaan, dan kepedulian terhadap orang lain. Warga negara diposisikan sebagai pemilik pemerintahan (owners of government) dan mampu bertindak secara bersama-sama mencapai sesuatu yang lebih baik. Kepentingan publik tidak lagi dipandang sebagai agregasi kepentingan pribadi melainkan sebagai hasil dialog dan keterlibatan publik dalam mencari nilai bersama dan kepentingan bersama.

Perspektif new public service menghendaki peran administrator publik untuk melibatkan masyarakat dalam pemerintahan dan bertugas untuk melayani masyarakat. Dalam menjalankan tugas tersebut, administrator publik menyadari adanya beberapa lapisan kompleks tanggung jawab, etika, dan akuntabilitas dalam suatu sistem demokrasi. Administrator yang bertanggung jawab harus melibatkan masyarakat tidak hanya dalam perencanaan tetapi juga pelaksanaan program guna mencapai tujuan-tujuan masyarakat.

Hal ini harus dilakukan tidak saja karena untuk menciptakan pemerintahan yang lebih baik tetapi juga sesuai dengan nilai-nilai demokrasi. Dengan demikian, pekerjaan administrator publik tidak lagi mengarahkan atau memanipulasi insentif tetapi pelayanan kepada masyarakat.

Akar dari NPS dapat ditelusuri dari berbagai ide tentang demokrasi yang pernah dikemukakan oleh Dimock, Dahl dan Waldo. NPS berakar dari beberapa teori, yang meliputi:

1. Teori tentang demokrasi kewarganegaraan; perlunya pelibatan warganegara dalam pengambilan kebijakan dan pentingnya deliberasi untuk membangun solidaritas dan komitmen guna menghindari konflik.

2. Model komunitas dan masyarakat sipil; akomodatif terhadap peran masyarakat sipil dengan membangun social trust, kohesi sosial dan jaringan sosial dalam tata pemerintahan yang demokratis.

3. Teori organisasi humanis dan administrasi negara baru; administrasi negara harus fokus pada organisasi yang menghargai nilai-nilai kemanusiaan (human beings) dan respon terhadap nilai-nilai kemanusiaan, keadilan dan isu-isu sosial lainnya.

4. Administrasi negara postmodern; mengutamakan dialog (dirkursus) terhadap teori dalam memecahkan persoalan publik daripada menggunakan one best way perspective.

Dilihat dari teori yang mendasari munculnya NPS, nampak bahwa NPS mencoba mengartikulasikan berbagi teori dalam menganalisis persoalan-persoalan publik. Oleh karena itu, dilihat dari berbagai aspek, menurut Denhardt dan Denhardt paradigma NPS memiliki 
perbedaan karakteristik dengan OPA dan NPM. Perbedaan tersebut dapat dilihat pada tabel di bawah ini.

Tabel 1. Diferensiasi OPA, NPM dan NPS

\begin{tabular}{|c|c|c|c|}
\hline Aspek & $\begin{array}{c}\text { Old Public } \\
\text { Administration }\end{array}$ & $\begin{array}{l}\text { New Public } \\
\text { Management }\end{array}$ & New Public Service \\
\hline $\begin{array}{l}\text { Dasar teoritis } \\
\text { dan } \\
\text { fondasi } \\
\text { epistimologi }\end{array}$ & Teori politik & Teori ekonomi & Teori demokrasi \\
\hline $\begin{array}{l}\text { Rasionalitas dan } \\
\text { model perilaku } \\
\text { Manusia }\end{array}$ & $\begin{array}{l}\text { Rasionalitas Synoptic } \\
\text { (administrative man) }\end{array}$ & $\begin{array}{l}\text { Teknis dan rasionalitas } \\
\text { ekonomi (economic } \\
\text { man) }\end{array}$ & $\begin{array}{l}\text { Rasionalitas strategis } \\
\text { atau rasionaitas } \\
\text { formal (politik, } \\
\text { ekonomi dan } \\
\text { organisasi) }\end{array}$ \\
\hline $\begin{array}{l}\text { Konsep } \\
\text { kepentingan } \\
\text { publik }\end{array}$ & $\begin{array}{l}\text { Kepentingan publik } \\
\text { secara politis } \\
\text { dijelaskan dan } \\
\text { diekspresikan dalam } \\
\text { aturan hukum }\end{array}$ & $\begin{array}{l}\text { Kepentingan publik } \\
\text { mewakili agregasi } \\
\text { kepentingan individu }\end{array}$ & $\begin{array}{l}\text { Kepentingan publik } \\
\text { adalah hasil dialog } \\
\text { berbagai nilai }\end{array}$ \\
\hline $\begin{array}{l}\text { Responsivitas } \\
\text { birokrasi publik }\end{array}$ & $\begin{array}{l}\text { Clients dan } \\
\text { constituent }\end{array}$ & Customer & Citizen"s \\
\hline $\begin{array}{l}\text { Peran } \\
\text { pemerintah }\end{array}$ & Rowing & Steering & Serving \\
\hline $\begin{array}{l}\text { Pencapaian } \\
\text { tujuan }\end{array}$ & Badan pemerintah & $\begin{array}{l}\text { Organisasi privat dan } \\
\text { nonprofit }\end{array}$ & $\begin{array}{l}\text { Koalisi } \\
\text { antarorganisasi } \\
\text { publik, nonprofit dan } \\
\text { privat }\end{array}$ \\
\hline Akuntabilitas & $\begin{array}{l}\text { Hierarki administratif } \\
\text { dengan jenjang yang } \\
\text { tegas }\end{array}$ & $\begin{array}{l}\text { Bekerja sesuai dengan } \\
\text { kehendak pasar } \\
\text { (keinginan pelanggan) }\end{array}$ & $\begin{array}{l}\text { Multiaspek: } \\
\text { akuntabilitas } \\
\text { hukum, nilai-nilai, } \\
\text { komunitas, norma } \\
\text { politik, standar } \\
\text { profesional }\end{array}$ \\
\hline $\begin{array}{l}\text { Diskresi } \\
\text { administrasi }\end{array}$ & Diskresi terbatas & $\begin{array}{l}\text { Diskresi diberikan } \\
\text { secara luas }\end{array}$ & $\begin{array}{l}\text { Diskresi dibutuhkan } \\
\text { tetapi dibatasi dan } \\
\text { bertanggung-jawab }\end{array}$ \\
\hline $\begin{array}{l}\text { Struktur } \\
\text { organisasi }\end{array}$ & $\begin{array}{l}\text { Birokratik yang } \\
\text { ditandai } \\
\text { dengan otoritas top- } \\
\text { down }\end{array}$ & $\begin{array}{l}\text { Desentralisasi } \\
\text { organisasi dengan } \\
\text { kontrol utama berada } \\
\text { pada para agen }\end{array}$ & $\begin{array}{l}\text { Struktur kolaboratif } \\
\text { dengan kepemilikan } \\
\text { yang berbagi secara } \\
\text { internal dan eksternal }\end{array}$ \\
\hline $\begin{array}{l}\text { Asumsi } \\
\text { terhadap } \\
\text { motivasi } \\
\text { pegawai } \\
\text { dan } \\
\text { administrator }\end{array}$ & $\begin{array}{l}\text { Gaji dan keuntungan, } \\
\text { proteksi }\end{array}$ & Semangat entrepreneur & $\begin{array}{l}\text { Pelayanan publik } \\
\text { dengan } \\
\text { keinginan melayani } \\
\text { masyarakat }\end{array}$ \\
\hline
\end{tabular}

Sumber: Denhardt dan Denhardt (2003: 28-29) 
Seperti halnya Osborne dan Gaebler, Denhardt dan Denhardt juga merumuskan prinsipprinsip NPS yang memiliki diferensiasi dengan prinsip-prinsip OPA dan NPM. NPS mengajak pemerintah untuk:

1. Melayani masyarakat sebagai warga negara, bukan pelanggan; melalui pajak yang mereka bayarkan maka warga negara adalah pemilik sah (legitimate) negara bukan pelanggan.

2. Memenuhi kepentingan publik; kepentingan publik seringkali berbeda dan kompleks, tetapi negara berkewajiban untuk memenuhinya. Negara tidak boleh melempar tanggung-jawabnya kepada pihak lain dalam memenuhi kepentingan publik.

3. Mengutamakan warganegara di atas kewirausahaan; kewirausahaan itu penting, tetapi warga negara berada di atas segala-galanya.

4. Berpikir strategis dan bertindak demokratis; pemerintah harus mampu bertindak cepat dan menggunakan pendekatan dialog dalam menyelesaikan persoalan publik.

5. Menyadari komplekstitas akuntabilitas; pertanggungjawaban merupakan proses yang sulit dan terukur sehingga harus dilakukan dengan metode yang tepat.

6. Melayani bukan mengarahkan; fungsi utama pemerintah adalah melayani warga negara bukan mengarahkan.

7. Mengutamakan kepentingan masyarakat bukan produktivitas; kepentingan masyarakat harus menjadi prioritas meskipun bertentangan dengan nilai-nilai produktivitas.

\section{Otokritik terhadap NPS}

NPS adalah cara pandang baru dalam administrasi negara yang mencoba menutupi (cover) kelemahan-kelemahan paradigma OPA dan NPM. Namun demkian, apakah NPS tidak memiliki kekurangan? Berikut ini akan diuraikan beberapa kritik terkait dengan beberapa kelemahan NPS.

\section{Pendekatan politik dalam administrasi negara}

Secara epistimologis, NPS berakar dari filsafat politik tentang demokrasi. Denhardt dan Denhardt menspesifikasikkannya menjadi demokrasi kewargaaan. Demokrasi merupakan suatu paham pemerintahan yang berdasarkan pada aturan untuk mewujudkan kesejahteraan dan kebaikan bersama. Dalam konteks demokrasi kewargaan, demokrasi dalam hal ini dimaknai sebagai pemerintahan yang berorientasi pada kepentingan warga negara secara keseluruhan. Warga negara memiliki hak penuh memperoleh perhatian dari pemerintah dan warga negara berhak terlibat dalam setiap proses pemerintahan (politik dan pengambilan kebijakan).

Denhardt dan Denhardt berhasil mencari akar mengapa pemerintah harus melayani (serve) bukan mengarahkan (steer), mengapa pemerintah memberikan pelayanan kepada masyarakat sebagai warga negara (citizens) bukan sebagai pelanggan (customers), tetapi mereka lupa bahwa nalar politik telah masuk dalam upaya pencarian state of the art administrasi negara-pelayanan publik. Lebih jauh, Denhardt dan Denhardt telah terjerembab dalam pendulum administrasi negara sebagai ilmu politik (paradigma 3). Padahal, dengan merumuskan NPS sebagai antitesa terhadap NPM berarti mereka meyakini bahwa administrasi negara telah bergerak melewati paradigma 5 .

Tidak ada yang salah ketika Denhardt dan Denhardt mencari akar ideologis paradigma NPS dari teori-teori politik karena administrasi negara sangat dipengaruhi oleh ilmu politik. Hanya saja nalar politik seperti ini harus diwaspadai sebagai upaya merewind administrasi negara sebagai ilmu politik. Semestinya Denhardt dan Denhardt dapat menggunakan nalar administrasi negara dalam mencari akar dan prinsip-prinsip NPS yang bisa dikonstatasikan dengan NPM. Misalnya, Denhardt dan Denhardt dapat meyakinkan orang lain bahwa pemerintah bertanggung-jawab melayani masyarakat sebagai warga negara karena pada awalnya warga negaralah yang mendirikan negara dan kemudian menjalankannya serta 
terikat dengan aturan-aturan negara. Oleh karena itu, secara etika dan moral warga negara adalah pemilik negara.

\section{Standar ganda dalam mengkritik NPM}

NPS berusaha mengkritik NPM, tetapi tidak tegas karena kritikan terhadap NPS hanyalah kritik secara filosofis-ideologis bukan kritik atas realitas pelaksanaan NPM yang gagal di banyak negara. NPM memang sukses diterapkan di Amerika Serikat, Kanada, Inggris, Selandia Baru dan beberapa negara maju lainnya, tetapi bagaimana penerapannya di negaranegara berkembang? Kenyataannya, banyak negara berkembang, termasuk Indonesia dan negara miskin, seperti negara-negara di kawasan benua Afrika yang gagal menerapkan konsep NPM karena tidak sesuai dengan landasan ideologi, politik, ekonomi dan sosialbudaya negara yang bersangkutan. Akhirnya, negara tersebut tetap miskin dan tidak menunjukkan adanya tanda-tanda kemajuan.

Denhardt dan Denhardt mengkritik NPS sebagai konsep yang salah dalam memandang masyarakat yang dilayani. NPM memandang masyarakat yang dilayani sebagai customer, sedangkan NPS menganggap masyarakat yang dilayani sebagai warga negara (citizens). Namun, Denhardt dan Denhardt lupa mencari akar ideologis, mengapa NPM memiliki perspektif demikian dalam memandang subjek pelayanan? mengapa NPM menawarkan “jurus” privatisasi, liberalisasi dan deregulasi untuk mendongkrak kinerja pemerintah? Tidak bisa dipungkiri bahwa NPM adalah anak ideologis neoliberalisme yang mencoba menerapkan mekanisme pasar dan berupaya secara sistematis mereduksi peran pemerintah, sehingga pemerintah menurut konsep berada di belakang kemudi kapal, sedangkan kapalnya dijalankan oleh organ-organ di luar pemerintah.

Dalam konsep NPS yang diajukan oleh Denhardt dan Denhardt nilai-nilai neoliberalisme NPM tidak hilang secara otomatis. Ketika pemerintah melayani masyarakat sebagai warga negara misalnya, aspek privatisasi bisa saja tetap berlangsung asalkan atas nama melayani kepentingan warga negara bukan pelanggan. Misalnya, sektor pendidikan dapat diprivatisasi asalkan pelaksana pendidikan tetap melayani masyarakat sebagai warga negara bukan pelanggan.

\section{Aplikasi NPS masih diragukan}

Prinsip-prinsip NPS belum tentu bisa diaplikasikan pada semua tempat, situasi dan kondisi. Administrasi negara sangat dipengaruhi oleh faktor lingkungan (ideologi, politik, hukum, ekonomi, militer, sosial dan budaya), sehingga suatu paradigma yang sukses di suatu tempat belum tentu berhasil diterapkan pada tempat yang lain. Prinsip-prinsip NPS masih terlalu abstrak dan perlu dikonkritkan lagi. Prinsip dasar NPS barangkali bisa diterima semua pihak, namun bagaimana prinsip ini bisa diimplementasikan sangat bergantung pada aspek lingkungan.

Lagi pula, NPS terlalu mensimplifikasikan peran pemerintah pada aspek pelayanan publik. Padahal, urusan pemerintah tidak hanya berkaitan dengan bagaimana menyelenggarakan pelayanan publik, tetapi juga menyangkut bagaimana melakukan pembangunan dan meningkatkan kesejahteraan masyarakat. Di negara-negara maju seperti di Amerika Serikat, Inggris dan Selandia Baru yang tidak lagi berkutat pada upaya percepatan pembangunan (development acceleration) dan peningkatan pertumbuhan ekonomi karena negara-negara tersebut relatif sudah stabil, maka pelayanan publik menjadi program prioritas yang strategis. Namun, bagi negara-negara berkembang, pelayanan publik bisa jadi belum menjadi agenda prioritas karena masih berupaya mengejar pertumbuhan dan meningkatkan pembangunan. 


\section{PENUTUP}

Berdasarkan tulisan di atas kita telah mengetahui bahwa sebenarrnya pengaruh ekologi sangat kuat posisinya dalam menentukan perkembangan dan pembentukan suatu bentuk paradigma di dalam ilmu Administrasi Publik. Seringkali terjadi perdebatan mengenai paradigma apa yang paling baik untuk diadopsi dalam menjalankan suatu sistem pemerintahan. Tetapi yang terpenting adalah bukan paradigma apa yang dianut suatu negara dalam menjalankan sistem pemerintahannya, karena tidak ada satu pun paradigma yang paling "sempurna” melainkan bagaimana masyarakat dapat mendapatkan pelayanan yang baik sehingga tercapai kesejahteraan yang menyeluruh di dalam negara tersebut.

\section{REFERENSI}

Barzelay, Michael (1992) Breaking Through Bureaucracy: A New Vision for Managing in Government, Berkeley and Los Angeles: University of California Press.

(1997) Researching The Politics of New Public Management: Changing The Question, Not The Subject, Paper delivered at the Summer Workshop of the International Public Management Network Berlin/ Potsdam, Germany, June 25-27, 1997.

, (2001) Researching the New Public Management, Lecturing Notes, London School of Economics and Political Science.

Broadbent, J. and Guthrie, J. (1992) "Changes in the Public Sector: A Review of Recent

„Alternative ${ }^{e e}$ Accounting Research,” Accounting, Auditing \& Accountability Journal, Vol. 5 No. 2, pp. 3-31.

Denhardt, J.V. \& Denhardt, R.B. (2004). The New Public Service: Serving, Not Steering. New York: M.E. Sharpe,

Di Francisco, Mickael (2001) “Process not Outcomes in New Public Management? „Policy Coherence ee in Australian Government," The Drawing Board: An Australian Review of Public Affairs, Vol. 1, No. 3 (March 2001), pp. 103-116.

Henry, Nicholas. (1995). Public Administration and Public Affairs (Sixth Edition).

Englewood Cliffs, New Jersey: Prentice-Hall.

Hughes, O. E. (1998) Public Management and Administration, 2nd Ed., London: MacMillan Press Ltd.

Keban, Yeremias T. 2004. Enam Dimensi Strategis Administrasi Publik: Konsep, Teori dan Isu (Edisi Pertama). Yogyakarta: Gava Media

Kurniawan, Teguh (2007) Pergeseran Paradigma dministrasi Publik: dari Perilaku Model Klasik dan NPM ke Good Governance, JIANA : Jurnal Ilmu Administrasi Negara Volume 7, 1 Januari 2007.

Muluk, M.R. Khairul, New Public Service Dan Pemerintahan Lokal Partisipatif.

Osborne, David and Gaebler, T. (1992) Reinventing Government: How the Entrepreneurial Spirit Is Transforming the Public Sector, New York: Penguins Books.

Thoha, Miftah, (2009) . Ilmu Administrasi Publik Kontemporer. Jakarta: Kencana. 
Tjokrowinoto, Moeljarto. (1996). "Perkembangan Mutakhir Ilmu Administrasi Negara”. Teori-teori Politik Dewasa Ini. Penyunting: Miriam Budiardjo dan Tri Nuke Pudjiastuti. Jakarta: Rajawali Pers.

Polidano, Charles (1999) "The New Public Management in Developing Countries," PublicPolicy and Management Working Paper No. 13 (November 1999), Institute for Development Policy and Management, University of Manchester.

Stewart and Ranson (1988) Management in the Public Domain, Public Money and Management, Vol. 89, No.1/2.

Yudiatmaja, Wayu Eko (2010) The New Public Service : Nalar Politik dalam Administrasi Negara. Artikel dalam www.academia.edu. 